\title{
Pengarah Suara Pada Sistem Audio Berdasarkan Beda Phasa Menggunakan Fpga
}

\author{
Olly Bangon Baskhoro, Muhammad Rivai, dan Fajar Budiman \\ Departemen Teknik Elektro, Fakultas Teknologi Elektro, Institut Teknologi Sepuluh Nopember (ITS) \\ e-mail:muhammad_rivai@ee.its.ac.id,fajarbudiman@ee.its.ac.id
}

\begin{abstract}
Abstrak-Pemberian informasi seperti pengumuman, ceramah, dan musik sering dilakukan dalam berbagai acara yang memerlukan ruangan yang luas. Supaya pemberian informasi hanya mencapai target yang dituju dan tidak mengganggu pengunjung lain maka suara harus diarahkan untuk lokasi tertentu. Pada penelitian ini telah dilakukan sebuah perancangan dan realisasi sistem deret speaker dimana intensitas sinyal suara dapat diarahkan dengan sudut kemiringan antara $-\mathbf{9 0}^{\circ}$ sampai $90^{\circ}$. Untuk menghindari munculnya intensitas suara pada arah yang berlawanan maka jarak antar titik pusat speaker untuk frekuensi $2 \mathrm{kHz}$ adalah 8,6 centimeter. Pengarahan suara dilakukan dengan cara memberikan waktu tunda di setiap speaker dengan menggunakan Field Programable Gate Array ALTERA DE-2. Sinyal audio dikonversi dengan menggunakan Analog to Digital Converter 24-bit. Waktu tunda tersebut dihasilkan dengan menggunakan sub program 8-bit D flip-flop dengan clock input sebasar 1 mikro detik. Data pengujian dengan menggunakan osiloskop menunjukkan untuk waktu tunda pada beda phasa $-\mathbf{9 0}^{\circ}$ sampai $90^{\circ}$ memiliki rata-rata kesalahan 3,5\%. Data hasil pengujian lobe deret speaker menunjukkan rerata kesalahan pengarahan suara sebesar $19 \%$. Sistem ini diharapkan dapat diterapkan pada berbagai aplikasi sehingga meningkatkan efisiensi penggunaan daya penguat audio dan mengurangi noise lingkungan.
\end{abstract}

Kata Kunci-Audio beam steering, Beda phasa, Deret Speaker, Field Programable Gate Array.

\section{PENDAHULUAN}

A UDIEN yang banyak dalam gedung olah raga, konser, dan aula perlombaan memerlukan sistem penguat suara yang memadai. Konfigurasi speaker yang tetap posisinya tidak optimal karena posisi audien selalu berubah. Intensitas suara yang difokuskan ke audien akan membuat sistem lebih baik karena pantulan suara yang tidak diinginkan menimbulkan gema dan menurunkan kualitas suara [1]. Salah mengarahkan suara dapat mengganggu orang lain. Selain itu, seseorang cenderung mengalami gangguan pendengaran jika secara kontinyu mendengarkan kebisingan dengan intensitas suara sebesar $85 \mathrm{~dB}$ [2]. Gema dapat diantisipasi dengan menambahkan peredam pada dinding, sedangkan kesalahan arah dapat diatasi dengan mengganti arah speaker.

Pada penelitian ini dirancang sebuah sistem pengarah suara yang terdiri dari rangkaian analog to digital converter, pengaturan waktu tunda dengan menggunakan Field Programmable Gate Array, rangkaian digital to analog, rangkaian penguat, dan speaker. Waktu tunda digunakan untuk mengubah arah suara tanpa mengganti posisi speaker.

\section{TEORI PENUNJANG}

Deret speaker merupakan sejumlah elemen speaker yang identik dan disusun dalam satu garis yang disebut line array speakers. Teori dari deret speaker didasarkan pada geometri dan eksperimen pada bidang bebas dimana suara dapat menyebar secara bebas dari faktor lingkungan seperti gangguan pantulan pada ruangan dan pembelokan arah yang dikarenakan temperatur. Deret speaker juga sering digunakan di area lokal atau auditorium untuk penguatan suara terarah [3].

Speaker tunggal atau suara dari satu sumber merupakan speaker yang memiliki keunggulan penyebaran yang luas, dan ukuran speaker bervariasi. Speaker tunggal memiliki tingkat penyebaran sesuai ukurannya dan desain frekuensi kerjanya. Tetapi bila diinginkan suara dapat sampai pada jarak dan pendengar yang banyak maka suara satu sumber memerlukan daya yang besar bila dibandingkan output sejumlah speaker secara bersamaan.

Suara deret speaker memiliki pola yang dapat diatur penyebarannya (main lobe), selain itu suara deret speaker dapat terdengar sama kuatnya dengan suara satu sumber dengan daya yang lebih kecil. Interferensi suara satu sama lain mengakibatkan suara pada deret speaker tidak menyebar melainkan terfokus sehingga jangkauan suara lebih jauh dengan daya yang lebih kecil.

Audio beam steering merupakan teknik untuk mengarahkan sinyal suara dengan menggunakan perangkat keluaran berupa speaker yang dijajar tanpa menggerakkan speaker tersebut [4]. Constructive interference merupakan insterferensi dari dua gelombang atau lebih dengan frekuensi dan fasa yang sama yang menghasilkan penguatan dan amplitudo berupa total kedua gelombang, ditunjukkan pada gambar 1 .



Gambar 1. Contructive Interference [4] 


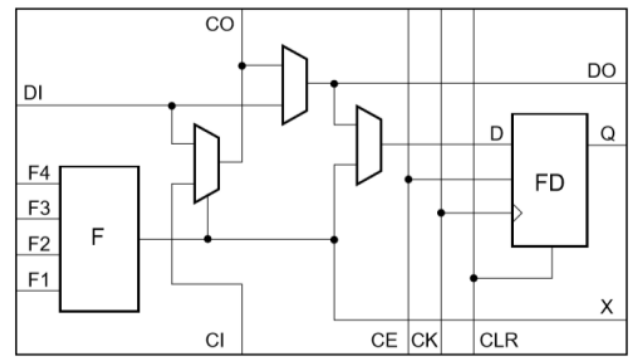

Gambar 2. Logic Cell pada FPGA [5]

Apabila sinyal yang keluar dari dua buah speaker koheren atau keluar bersamaan dengan sudut fasa yang sama, maka sinyal akan saling menguatkan pada arah lurus di depan speaker. Jika arah yang diinginkan oleh pengguna tidak lurus maka akan terdapat perbedaan panjang gelombang suara yang keluar dari speaker, sehingga jika diinginkan terjadi constructive interference pada kemiringan sudut tertentu akan diperlukan waktu tunda pada speaker supaya panjang gelombang yang sampai ke titik pendengar sama [6].

Field Programmable Gate Array (FPGA) merupakan komponen elektronika dan semikonduktor yang mempunyai komponen gerbang terprogram dan sambungan terprogram. Secara umum FPGA terdiri dari logic block dan blok inputoutput. Semua blok didalamnya dapat diprogram sampai pada skala tertentu. Generasi FPGA terbaru memiliki kemampuan yang tinggi dalam proses logika dengan konfigurasi mencapai $550 \mathrm{MHz}$, dibandingkan dengan mikrokontroler yang hanya mampu sampai $24 \mathrm{Mhz}$ [7].

FPGA dapat digunakan untuk perancangan hardware digital yang terprogram seperti flip-flop, counter, shift register, dan komponen-komponen elektronika lainnya [8]. Bentuk FPGA tidak berbeda jauh dengan bentuk IC lainnya. Dilihat dari fungsi dan rangkaiannya, FPGA memiliki bagian yang berbeda dengan komponen IC pada umumnya. Berikut isi dari FPGA pada umumnya:

- Configure Logic Blocks (CLB). Bagian yang memproses segala bentuk rangkaian logika yang dibuat oleh user atau pemakai.

- I/O Blocks. Sebagai interface antara external pin dari device dan internal user logic.

- Programmable Interconnect. Bagian ini berisi wire segments dan programmable switches, selain itu bagian ini juga akan menghubungkan antara CLB satu dengan CLB lainnya.

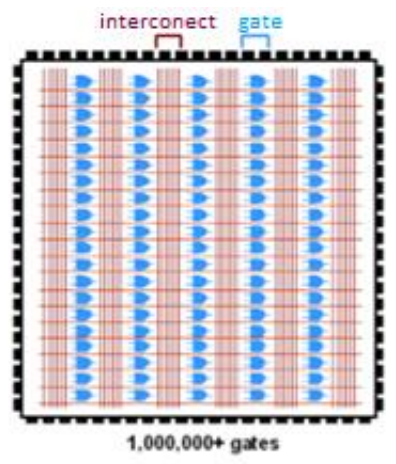

Gambar 3. Bagian isi dari FPGA buatan Xilinx [5]
FPGA tersusun dari sebuah bagian yang bernama logic-cell atau Logic Blocks seperti ditunjukkan pada gambar 2, yang saling terhubung satu sama lain. Kumpulan dari logic cell ini berjumlah ratusan bahkan ribuan dan membentuk fungsi yang kompleks seperti gambar 3. Logic cell pada dasarnya terdiri atas sebuah lookup table (LUT), D flip-flop, dan sebuah 2-to-1 multiplexer [5]. LUT merupakan random access memory (RAM) yang berkapasitas kecil. LUT pada FPGA memegang peranan penting dalam proses implementasi berbagai fungsi logika.

Konverter digital ke analog adalah perangkat elektronika yang digunakan untuk mengubah data digital menjadi sinyal analog. Metode yang sering digunakan untuk membuat DAC adalah binary weighted dan R-2R ladder. DAC 0808 yang menggunakan metode R-2R dapat mencapai tingkat presisi tinggi dalam konversi data. Kriteria pertama untuk menilai DAC adalah resolusinya yang merupakan fungsi dari jumlah input biner [9].

Impedansi merupakan ukuran resistansi pada sumber arus AC. Impedansi adalah resistansi yang lebih kompleks dan akurat pada arus AC. Walaupun dalam speaker terdapat impedansi dan tidak mempengaruhi kualitas secara keseluruhan, tetapi secara otomatis akan mempengaruhi kerja sebuah sistem audio [10]. Speaker biasanya mempunyai impedansi sekitar $4 \mathrm{ohm}, 8 \mathrm{ohm}$ dan sebagainya. Impedansi berhubungan dengan arus. Semakin besar impedansi maka akan semakin kecil arus yang lewat, dan sebaliknya. Besar arus yang mengalir mempengaruhi daya maksimal yang dikeluarkan oleh suatu rangkaian.

\section{PERANCANGAN SISTEM}

Perancangan sistem dibagi menjadi 3 bagian yaitu kerangka speaker, rangkaian elektrik DAC0808, dan perangkat lunak waktu tunda pada board FPGA ALTERA DE-2. Pada gambar 4 menunjukkan diagram blok sistem. Deret speaker terdiri dari 5 buah speaker mengeluarkan suara dari rangkaian DAC0808 yang telah diberikan waktu tunda dari perangkat lunak pengaturan waktu tunda pada FPGA. Proses waktu tunda yang digunakan adalah memanfaatkan system kerja D flip-flop yang menahan data sampai terdapat rising edge pada clock yang telah ditentukan. Data yang dikeluarkan D flip-flop disimpan pada variabel yang ditentukan untuk penentuan waktu tunda yang diinginkan.

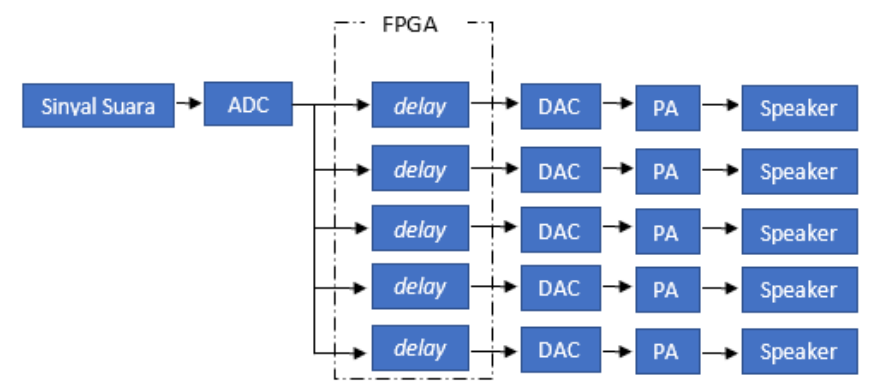

Gambar 4. Diagram blok sistem deret speaker. 


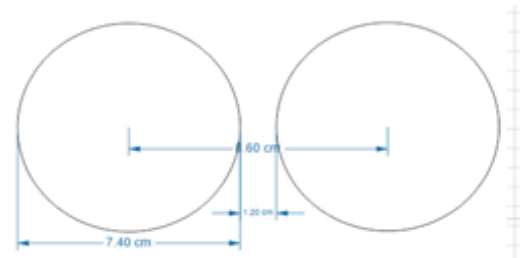

Gambar 5. Perancangan jarak antara speaker

Sinyal input berupa audio dari handphone atau komputer diubah menjadi data digital oleh audio codec Wolfson WM8731 yang ada pada build in board ALTERA DE-2. Resolusi dari audio codec Wolfson WM8731 adalah 24-bit sedangkan DAC yang digunakan adalah 8-bit, sehingga data yang diproses untuk diterapkan waktu tunda adalah 8-bit MSB dari data 24-bit ADC.

Deret speaker dirancang dengan memperhitungkan jarak antar titik tengah speaker, ditunjukkan pada gambar 5. Hal ini bertujuan untuk mencegah munculnya sinyal dengan intensitas yang sama tetapi dengan arah yang berlawanan atau biasa disebut grating lobe. Untuk menghindari grating lobe dapat diterapkan persamaan 1 .

$$
d<\frac{\lambda}{1+\sin x}
$$

dimana $\mathrm{x}$ merupakan nilai dari sudut kemiringan terbesar dalam perancangan system deret speaker, $\lambda$ panjang gelombang dari gelombang suara, c kecepatan suara dalam udara $344 \mathrm{~m} / \mathrm{d}$ pada $20^{\circ} \mathrm{C}$, f frekuensi gelombang, d jarak antara titik pusat speaker.

$$
\begin{gathered}
d<\frac{\lambda}{1+\sin 90} \\
\lambda=\frac{c}{\mathrm{f}} \\
d=\frac{c}{2 * \mathrm{f}}
\end{gathered}
$$

Dengan memperhitungkan lebar speaker dan frekuensi maksimum suara maka didapatkan hasil dengan frekuensi tertinggi yaitu:

Tabel 1.

Hasil perhitungan jarak titik pusat speaker.

\begin{tabular}{cc}
\hline \hline Frekuensi $(\mathrm{Hz})$ & $\mathrm{d}(\mathrm{cm})$ \\
\hline 1700 & 10,11765 \\
1800 & 9,555556 \\
1900 & 9,052632 \\
2000 & 8,6 \\
\hline \hline
\end{tabular}

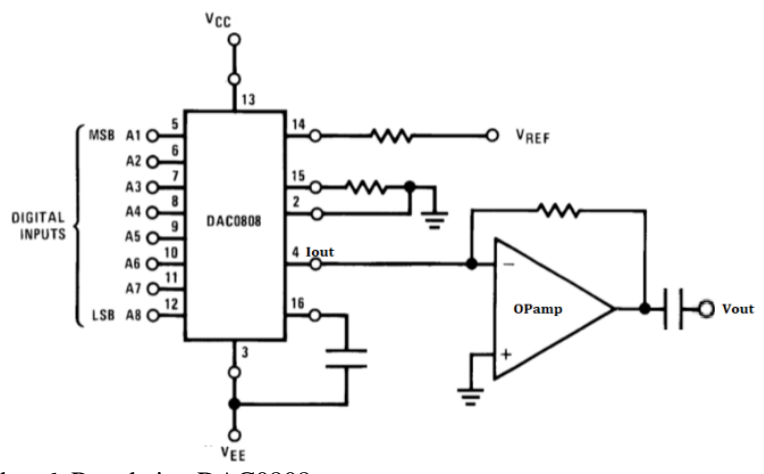

Gambar 6. Rangkaian DAC0808.

- $\quad$ Spesifikasi speaker 10 watt, $4 \mathrm{ohm}$, diameter $7.4 \mathrm{~cm}$

- Frekuensi $300 \mathrm{~Hz}-20 \mathrm{KHz}$

Hasil dari perhitungan dapat dilihat pada tabel 1. Untuk frekuensi $2 \mathrm{Khz}$ dengan diameter speaker 7,4cm maka jarak antara titik pusat sebesar:

$$
d=\frac{34400 \mathrm{~cm}}{2000 \mathrm{hz} * 2}=8,6 \mathrm{~cm}
$$

Gambar 6 menunjukkan perancangan rangkaian DAC0808 yang berfungsi untuk merubah data dari GPIO board Altera DE2 menjadi sinyal audio sehingga sinyal dapat dikuatkan dan dikeluarkan pada speaker. Tegangan referensi yang digunakan adalah 5 volt. Opamp pada rangkaian DAC ini berfungsi sebagai komponen yang mengubah arus menjadi tegangan. Sinyal analog yang dihasilkan kemudian dilewatkan melalui kapasitor untuk menghilangkan nilai tegangan DC nya.

Berdasarkan teknik beam steering bahwa pada deret speaker merupakan interferensi dari dua gelombang atau lebih dengan frekuensi dan phasa yang sama akan menghasilkan amplitudo dari jumlah gelombangnya. Bila diinginkan suara yang dikeluarkan oleh deret speaker terdengar pada titik tertentu dengan sudut kemiringan $\mathrm{x}$, maka suara yang dikeluarkan oleh speaker harus memiliki phasa yang sama pada titik dengar. Oleh karena itu suara pada speaker harus diterapkan waktu tunda supaya suara pada sudut kemiringan tersebut dapat dikuatkan pada titik dengar. Gambar 7 menunjukkan interferensi suara di titik dengar dengan jarak antara titik pusat speaker (d).

Dari segitiga siku-siku pada gambar 8 dapat dicari persamaan waktu tunda dengan penurunan persamaan sebagai berikut:

$$
\begin{aligned}
& y=180^{\circ}-90^{\circ}-(90-x) \\
& y=x
\end{aligned}
$$






Gambar 7. Pengarahan suara pada deret speaker

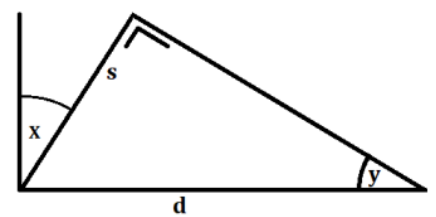

Gambar 8. Segitiga siku - siku dari hasil pengarahan suara.

Dari persamaan 7 dimana sudut $\mathrm{x}$ sama dengan sudut y dan berdasarkan persamaan trigonometri pada kuadran pertama dimana $\operatorname{Sin} \alpha=\frac{\mathrm{y}}{\mathrm{r}}$ (y adalah sisi tegak dan $\mathrm{r}$ adalah sisi miring), didapatkan persamaan:

$$
\begin{aligned}
& \operatorname{Sin} x=\frac{s}{d} \\
& s=d * \sin x
\end{aligned}
$$

Bila 's' merupakan hasil kali dari ' $c * \tau$ ', maka persamaan 9 dapat diturunkan menjadi:

$$
c * \tau=d * \sin x
$$

Nilai dari kecepatan suara di udara (c) dan jarak antara titik pusat pada speaker (d) merupakan suatu kostanta. Jika sudut kemiringan sinyal output pada pada sistem deret speaker ingin diubah, maka nilai yang dapat dirubah adalah nilai $\tau$ atau waktu tundanya, sehingga persamaan 10 dapat diturunkan menjadi:

$$
\tau=(d * \sin x) / c
$$

Dari persamaan 11 dapat dihitung waktu yang diperlukan untuk setiap speaker supaya suara dapat mengarahkan suara pada sudut kemiringan tertentu. Jika diinginkan kemiringan pada sudut $30^{\circ}$, maka nilai waktu tundanya adalah

$$
\begin{aligned}
\tau & =(0,086 * \sin 30) / 344 \\
\tau & =125 \mu \boldsymbol{S}
\end{aligned}
$$

Hasil perhitungan pada masing sudut kemiringan $0^{\circ}$ sampai $90^{0}$ dapat dilihat pada table 2 . Sebuah program waktu tunda dapat menirukan sistem kerja D flip - flop dimana data input ditahan sampai terdapat triger dari clock. Karena DAC untuk sistem pengarah suara ini memiliki konversi data input 8-bit maka perlu dirancang program D flip-flop untuk 8-bit. Untuk mempermudah perancangan dan menghemat memori, maka clock yang digunakan untuk D flip - flop adalah 1 mikro detik.
Tabel 2.

Hasil perhitungan waktu tunda

\begin{tabular}{cc}
\hline \hline Sudut $\left({ }^{\circ}\right)$ & Waktu tunda $(\mu \mathrm{s})$ \\
\hline 10 & 43.5 \\
20 & 85.5 \\
30 & 125 \\
40 & 160.75 \\
50 & 191.5 \\
60 & 216.5 \\
70 & 234.75 \\
80 & 246.25 \\
90 & 250 \\
\hline \hline
\end{tabular}



Gambar 9. Diagram alir program waktu tunda

Perangkat keras FPGA Altera DE-2 memiliki clock internal sebesar 20 nano detik sehingga dibutuhkan program clock devider untuk dapat digunakan pada perancangan program waktu tunda.

Gambar 9 menunjukkan diagram alir program waktu tunda. FPGA mendapat sinyal input memalui line in pada board dan kemudian diproses oleh Wolfson codec sehingga didapatkan data 24-bit. Data ADC tersebut diproses untuk diambil 8 bits MSB untuk dimasukkan ke variabel array data ke-0. Dari 8-bit data ke-0 dilakukan pemanggilan sub program D flip-flop 8-bit dengan triger clock sebesar 1 mikro detik untuk dimasukkan ke variabel array data ke-1. Proses ini akan dilakukan pemanggilan sub program D flip-flop 8-bit kembali untuk proses data ke-1 menuju data ke-2 dan seterusnya sampai variabel data ke-1000. 


\section{PENGUJIAN DAN ANALISIS DATA}

Pengujian waktu tunda dilakukan dengan memberikan sinyal sinus dari function generator ke line in pada board altera DE2. Kemudian diterapkan waktu tunda dari 43,5 mikro detik untuk kemiringan $10^{\circ}$ sampai 250 mikrodetik untuk kemiringan sudut $90^{\circ}$. Hasil pengujian ini ditunjukkan pada gambar 10 .

Pengujian sound lobe untuk sistem deret speaker dilakukan dengan memetakan hasil pengukuran dari besar itensitas suara (dB) menggunakan sound level meter dengan sudut kemiringan $-90^{\circ}$ sampai $90^{\circ}$. Hasil pemetaan sound lobe pada system deret speaker dapat dilihat pada gambar 11,12, 13 dan tabel 3. Hasil pengukuran tersebut dilakukan pemetaan dan diproses dengan pendekatan kurva polinomial orde 6 supaya dapat ditentukan nilai tertingginya.


(c)

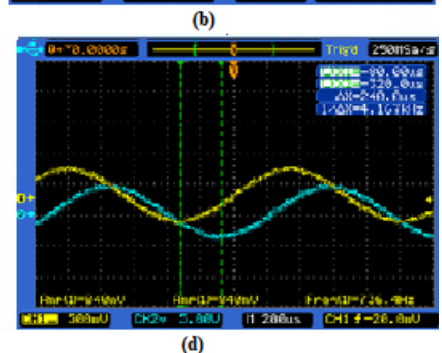

Gambar 10. Pengujian waktu tunda untuk variasi beda phasa: (a) $20^{\circ}$, (b) $50^{\circ}$, (c) $60^{\circ}$, (d) $80^{\circ}$,

Tabel 3 .

Hasil pengukuran itensitas suara

\begin{tabular}{|c|c|c|c|c|}
\hline \multirow{2}{*}{$\begin{array}{c}\text { Sudut } \\
\text { Referensi }\left(^{\circ}\right)\end{array}$} & \multicolumn{4}{|c|}{ Pengukuran $(\mathrm{db})$} \\
\cline { 2 - 5 } & $-90^{\circ}$ & $-60^{\circ}$ & $-30^{\circ}$ & $0^{\circ}$ \\
\hline-90 & 60,70 & 60,50 & 59,80 & 60,40 \\
-80 & 61,40 & 62,80 & 60,90 & 61,00 \\
-70 & 61,30 & 63,70 & 61,80 & 62,80 \\
-60 & 62,40 & 65,70 & 63,00 & 64,50 \\
-50 & 64,00 & 67,90 & 64,30 & 64,40 \\
-40 & 63,80 & 67,10 & 65,30 & 66,30 \\
-30 & 64,80 & 67,00 & 67,00 & 68,10 \\
-20 & 67,00 & 67,60 & 68,10 & 69,40 \\
-10 & 67,50 & 66,30 & 69,10 & 70,30 \\
0 & 64,50 & 67,30 & 68,80 & 72,50 \\
10 & 65,40 & 66,10 & 67,80 & 71,20 \\
20 & 64,90 & 66,40 & 68,00 & 68,90 \\
30 & 64,20 & 65,10 & 66,70 & 67,90 \\
40 & 63,70 & 64,30 & 64,90 & 67,30 \\
50 & 62,90 & 63,80 & 64,30 & 66,40 \\
60 & 62,80 & 63,40 & 63,80 & 65,40 \\
70 & 62,60 & 63,00 & 62,50 & 62,60 \\
80 & 61,70 & 62,50 & 61,60 & 60,10 \\
90 & 60,50 & 60,20 & 60,40 & 59,00 \\
\hline
\end{tabular}



Gambar 11. Hasil pengujian lobe untuk beda phasa $0^{\circ}$



Gambar 12. Hasil pengujian lobe untuk beda phasa $-60^{\circ}$.

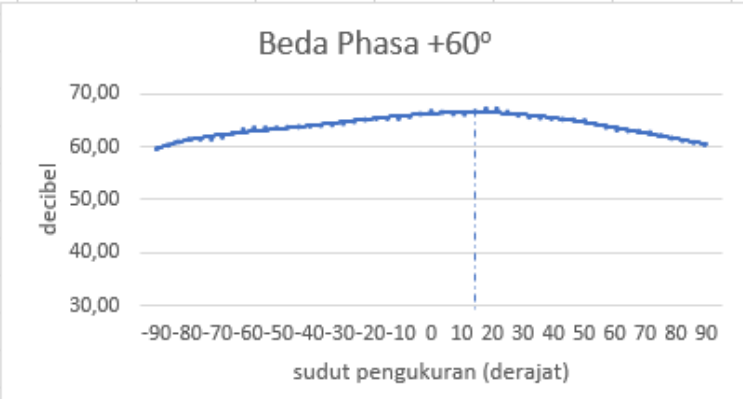

Gambar 13. Hasil pengujian lobe untuk beda phasa $+60^{\circ}$

Hasil pengambilan data pada sound lobe dilakukan perhitungan kesalahan terhadap sudut referensi, ditunjukkan pada persamaan 12. Hasil kesalahan sistem pengarahan dapat dilihat pada tabel 4 .

$$
\% \mathrm{e}=\left|\frac{\text { Referensi-Pengukuran }}{180^{\circ}}\right| \mathrm{x} 100 \%
$$

Tabel 4.

Hasil perhitungan kesalahan sistem pengarahan pada jarak pengukuran $4 \mathrm{~m}$.

\begin{tabular}{|c|c|c|}
\hline Sudut Pengarahan (derajat) & Sudut Terukur (derajat) & Kesalahan (\%) \\
\hline-90 & -10 & 44,4 \\
-60 & -28 & 17,8 \\
-30 & -3 & 15,0 \\
0 & 0 & 0,0 \\
30 & 1 & 16,1 \\
60 & 15 & 25,0 \\
90 & 18 & 40,0 \\
\hline
\end{tabular}




\section{KESIMPULAN}

Pada penelitian ini telah dilakukan rancang bangun sebuah sistem pengarah suara yang terdiri dari rangkaian analog to digital converter 24-bit, pengaturan waktu tunda $(0-250 \mu \mathrm{s})$ yang diterapkan dalam modul Field Programmable Gate Array Altera DE-2, rangkaian digital to analog converter 8-bit, rangkaian penguat audio, dan deret 5 speaker. Dengan menerapkan waktu tunda dapat mengubah arah suara mulai dari $-90^{\circ}$ sampai $90^{\circ}$ tanpa merubah posisi speaker. Hasil pengukuran menunjukkan bahwa waktu tunda yang dihasilkan pada perancangan ini terdapat rerata kesalahan sebesar 3,5\%. Hasil pengukuran intensitas suara dengan menggunakan sound level meter diperlukan untuk menggambarkan profil lobe intensitas suara yang dihasilkan ke segala arah. Rerata kesalahan pengukuran lobe suara pada jarak $1 \mathrm{~m}$ adalah $17 \%, 2$ m adalah $19 \%$ dan 4 m adalah $22 \%$.

\section{DAFTAR PUSTAKA}

[1] J. G. V. M. A. Martin O., Steffen S., Daniel F., "Digital Directivity Control of Loudspeakers for Sound Reinforcement.," 2008.
[2] A. H. R. Foundation, "Noise Induced Hearing Loss," Graphics are courtesy of Northwestern University, 2012.

[3] and K. L. G. Brian E. Anderson, Brad Moser, "Loudspeaker line array educational demonstration," Brigham Young University, 2011.

[4] and Q. H. YTang, Y Fang, "Multi-Beam Steering for 3D Audio Rendering in Linear Phased Loudspeaker Arrays," in Image Analysis and Signal Processing (IASP), International Conference, 2010.

[5] dan N. M. Karen Parnel, Programable Logic Design Quick Start Handbook, Fourth Edi. 2003.

[6] H. Habib, "Perancangan Audio Beam Steering Untuk Sistem Pengusiran Hama Burung," Inst. Teknol. Sepuluh Nop., 2017.

[7] R. D. Reza B. H., Muhammad Rivai, "Metode Pencacahan Frekuensi Reciprocal untuk Sensor Gas Resonator Kuarsa yang Diimplementasikan pada Field Programmable Gate Array," J. Tek. ITS, vol. 4, no. 1, pp. 2301-9271, 2017.

[8] dan M. R. Hari Agus S, "Vapor Identification System Using Quartz Resonator Sensor Array and Support Vector Machine," ARPN J. Eng. Appl. Sci., pp. 2426-2430, 2017.

[9] S. S. G. Tripathi, Shubhangi M., "DAC Interfacing with 805.1," Int. J. Res. Advent Technol., vol. 2, no. 2, pp. 963-2321, 2014.

[10] Altious, "Apa itu Impedansi pada Speaker," www.audioengine.co.id/ apa-itu-impedansi-pada-speaker, 2017. [Online]. Available: www.audioengine.co.id/ apa-itu-impedansi-pada-speaker. 